\title{
Phylogenetics of Sigmodontinae (Rodentia, Muroidea, Cricetidae), with special reference to the akodont group, and with additional comments on historical biogeography
}

\author{
Guillermo D’Elía ${ }^{a, b}$ \\ a The University of Michigan Museum of Zoology, Ann Arbor, USA \\ ${ }^{\mathrm{b}}$ Laboratorio de Evolución, Facultad de Ciencias, Igúa 4225 esq. Mataojo, Montevideo CP 11400, Uruguay
}

Accepted 6 June 2003

\begin{abstract}
This is the first cladistic analysis of sigmodontine rodents (Cricetidae, Sigmodontinae) based on nuclear and mitochondrial DNA sequences. Two most parsimonious cladograms (7410 steps in length; CI =0.199; RI =0.523) were discovered. Sigmodontinae appears well supported. Sigmodon is sister to the remaining living sigmodontines. It is shown that Euneomys is not a phyllotine and that the Reithrodon group is not monophyletic. Results corroborate that the abrothricines form a natural group that is not part of the akodont radiation. The akodontine tribe is well supported, and is composed of five main clades, whose limits and relationships are thoroughly discussed. For instance, the scapteromyines do not form a natural group and they fall within the akodontine clade. Additionally, I present some taxonomic judgments and comments on the historical biogeography of sigmodontines in the light of the newly discovered relationships. For example, five akodontine divisions are suggested: the Akodon, the Bibimys, the Blarinomys, the Oxymycterus, and the Scapteromys Divisions. It is shown that traditional hypotheses of sigmodontine historical biogeography are falsified by the recovered topology.
\end{abstract}

(c) 2003 The Willi Hennig Society. Published by Elsevier Inc. All rights reserved.

\section{Introduction}

With about 71 extant genera, muroids of the subfamily Sigmodontinae (sensu Reig, 1980) are one of the most diversified and complex groups of New World mammals. Sigmodontines are distributed predominantly in South America (around 60 endemic genera), although they also reach Central and North America (11 genera, of which only one, Rheomys, is not also present in South America). In addition, an extant genus is endemic to the Galapagos Islands. Notably, new sigmodontine genera are still being erected on the basis of both newly discovered species (e.g., Anderson and Yates, 2000) and from revisionary museum work (e.g., Voss et al., 2002).

The diversity of sigmodontine forms has long fascinated students of the New World fauna, and at the same

E-mail address: guillermo@fcien.edu.uy. time it has seriously challenged researchers attempting to study their phylogenetic relationships and classify them accordingly (Table 1). Problems range from species boundaries, to relationships among sigmodontine taxa, to the limits and contents of the higher taxa (e.g., subfamily). These issues have direct implications for the study of the history of the diversification of the group, which in turn arguably constitutes one of the most controversial debates in muroid systematics (see current state of the controversy in Pardiñas et al., 2002).

I have argued (D’Elía, 2000; Pardiñas et al., 2002) that our poor understanding of sigmodontine phylogenetics has hampered the debate on sigmodontine origins, including the limits and contents of the traditionally defined (based on overall similarity) groups of genera. This is true in spite of several studies on sigmodontine phylogenetics that have been published in the last decade. Most of these, which were based on molecular markers (but see also Steppan, 1995), were focused on relationships within particular genera (Bonvicino and 
Table 1

Three prominent suprageneric arrangements of sigmodontine rodents

\begin{tabular}{|c|c|c|c|c|c|}
\hline $\begin{array}{l}\text { Reig } \\
\text { (1986) }\end{array}$ & $\begin{array}{l}\text { McKenna and Bell } \\
\text { (1997) }\end{array}$ & $\begin{array}{l}\text { Smith and Patton } \\
\text { (1999) }\end{array}$ & $\begin{array}{l}\text { Reig } \\
(1986)\end{array}$ & $\begin{array}{l}\text { McKenna and Bell } \\
\text { (1997) }\end{array}$ & $\begin{array}{l}\text { Smith and Patton } \\
\text { (1999) }\end{array}$ \\
\hline $\begin{array}{l}\text { Akodontini } \\
\text { Akodon } \\
\text { Blarinomys } \\
\text { Necromys } \\
\text { Chelemys } \\
\text { Juscelinomys } \\
\text { Lenoxus } \\
\text { Microxus } \\
\text { Notiomys } \\
\text { Oxymycterus } \\
\text { Podoxymys }\end{array}$ & $\begin{array}{l}\text { Akodontini } \\
\text { Abrothrix } \\
\text { Akodon } \\
\text { Blarinomys } \\
\text { Chelemys } \\
\text { Chroeomys } \\
\text { Geoxus } \\
\text { Juscelinomys } \\
\text { Lenoxus } \\
\text { Necromys } \\
\text { Notiomys } \\
\text { Oxymycterus } \\
\text { Pearsonomys } \\
\text { Podoxymys } \\
\text { Thalpomys }\end{array}$ & $\begin{array}{l}\text { Akodontini } \\
\text { Akodon } \\
\text { Bibimys } \\
\text { Blarinomys } \\
\text { Brucepattersonius* } \\
\text { Juscelinomys } \\
\text { Kunsia } \\
\text { Lenoxus } \\
\text { Necromys } \\
\text { Oxymycterus } \\
\text { Podoxymys } \\
\text { Scapteromys } \\
\text { Thalpomys } \\
\text { Thaptomys }\end{array}$ & $\begin{array}{l}\text { Oryzomyini } \\
\text { Aepeomys } \\
\text { Chilomys } \\
\text { Delomys } \\
\text { Neacomys } \\
\text { Nectomys } \\
\text { Nesoryzomys } \\
\text { Oecomys } \\
\text { Oryzomys } \\
\text { Phaenomys } \\
\text { Rhipidomys } \\
\text { Scolomys } \\
\text { Thomasomys } \\
\text { Wilfredomys }\end{array}$ & $\begin{array}{l}\text { Oryzomyini } \\
\text { Amphinectomys* } \\
\text { Holochilus } \\
\text { Melanomys } \\
\text { Lundomys* } \\
\text { Microakodontomys* } \\
\text { Microryzomys } \\
\text { Neacomys } \\
\text { Nectomys } \\
\text { Nesoryzomys } \\
\text { Oecomys } \\
\text { Oligoryzomys } \\
\text { Oryzomys } \\
\text { Pseudoryzomys } \\
\text { Scolomys } \\
\text { Sigmodontomys } \\
\text { Zygodontomys }\end{array}$ & $\begin{array}{l}\text { Oryzomyini } \\
\text { Holochilus } \\
\text { Lundomys } \\
\text { Melanomys } \\
\text { Microryzomys } \\
\text { Neacomys } \\
\text { Nectomys } \\
\text { Nesoryzomys } \\
\text { Oecomys } \\
\text { Oligoryzomys } \\
\text { Oryzomys } \\
\text { Pseudoryzomys } \\
\text { Sigmodontomys } \\
\text { Zygodontomys }\end{array}$ \\
\hline $\begin{array}{l}\text { Scapteromyini } \\
\text { Bibimys } \\
\text { Kunsia } \\
\text { Scapteromys }\end{array}$ & $\begin{array}{l}\text { Scapteromyini } \\
\text { Bibimys } \\
\text { Kunsia } \\
\text { Scapteromys }\end{array}$ & Not recognized & Not recognized & $\begin{array}{l}\text { Thomasomyini } \\
\text { Abrawayaomys } \\
\text { Aepeomys } \\
\text { Chilomys } \\
\text { Delomys } \\
\text { Phaenomys } \\
\text { Rhipidomys } \\
\text { Thomasomys } \\
\text { Wilfredomys }\end{array}$ & $\begin{array}{l}\text { Thomasomyini } \\
\text { Aepeomys } \\
\text { Chilomys } \\
\text { Rhipidomys } \\
\text { Thomasomys }\end{array}$ \\
\hline Not recognized & Not recognized & $\begin{array}{l}\text { "Abrothricines" } \\
\text { Abrothrix } \\
\text { Chelemys } \\
\text { Chroeomys } \\
\text { Geoxus } \\
\text { Notiomys } \\
\text { Pearsonomys }\end{array}$ & $\begin{array}{l}\text { Ichthyomyini } \\
\text { Anotomys } \\
\text { Daptomys } \\
\text { Ichthyomys } \\
\text { Neusticomys }\end{array}$ & $\begin{array}{l}\text { Ichthyomyini } \\
\text { Anotomys } \\
\text { Chibchanomys } \\
\text { Ichtyomys } \\
\text { Neusticomys } \\
\text { Rheomys }\end{array}$ & $\begin{array}{l}\text { Ichthyomyini } \\
\text { Anotomys } \\
\text { Chibchanomys } \\
\text { Ichtyomys } \\
\text { Neusticomys } \\
\text { Rheomys }\end{array}$ \\
\hline $\begin{array}{c}\text { Sigmodontini } \\
\text { Holochilus } \\
\text { Sigmodon }\end{array}$ & $\begin{array}{c}\text { Sigmodontini } \\
\text { Sigmodon }\end{array}$ & $\begin{array}{c}\text { Sigmodontini } \\
\text { Sigmodon }\end{array}$ & $\begin{array}{l}\text { Wiedomyini } \\
\text { Wiedomys }\end{array}$ & $\begin{array}{l}\text { Wiedomyini } \\
\text { Wiedomys }\end{array}$ & $\begin{array}{l}\text { Wiedomyini } \\
\text { Wiedomys }\end{array}$ \\
\hline $\begin{array}{l}\text { Phyllotini } \\
\text { Andalgalomys } \\
\text { Andinomys } \\
\text { Auliscomys } \\
\text { Calomys } \\
\text { Chinchillula } \\
\text { Eligmodontia } \\
\text { Euneomys } \\
\text { Galenomys } \\
\text { Graomys } \\
\text { Irenomys } \\
\text { Neotomys } \\
\text { Phyllotis } \\
\text { Pseudoryzomys } \\
\text { Reithrodon }\end{array}$ & $\begin{array}{l}\text { Phyllotini } \\
\text { Andinomys } \\
\text { Auliscomys } \\
\text { Calomys } \\
\text { Chinchillula } \\
\text { Eligmodontina } \\
\text { Euneomys } \\
\text { Galenomys } \\
\text { Graomys } \\
\text { Irenomys } \\
\text { Loxodontomys } \\
\text { Neotomys } \\
\text { Phyllotis } \\
\text { Punomys } \\
\text { Reithrodon } \\
\text { Salinomys* }\end{array}$ & $\begin{array}{l}\text { Phyllotini } \\
\text { Andalgalomys } \\
\text { Andinomys } \\
\text { Auliscomys } \\
\text { Calomys } \\
\text { Chinchillula } \\
\text { Eligmodontia } \\
\text { Euneomys } \\
\text { Galenomys } \\
\text { Graomys } \\
\text { Loxodontomys } \\
\text { Neotomys } \\
\text { Phyllotis } \\
\text { Salinomys }\end{array}$ & $\begin{array}{l}\text { Incertae sedis } \\
\text { Abrawayaomys } \\
\text { Punomys } \\
\text { Rhagomys } \\
\text { Zygodontomys }\end{array}$ & $\begin{array}{c}\text { Incertae sedis } \\
\text { Rhagomys }\end{array}$ & $\begin{array}{l}\text { Incertae sedis } \\
\text { Abrawayaomys } \\
\text { Microakodontomys } \\
\text { Phaenomys } \\
\text { Punomys } \\
\text { Rhagomys } \\
\text { "Additional unique lines" } \\
\text { Delomys } \\
\text { Irenomys } \\
\text { Reithrodon } \\
\text { Scolomys } \\
\text { Wilfredomys }\end{array}$ \\
\hline
\end{tabular}

Note. Necromys was referred to as Bolomys in all three classifications. Asterisks indicate genera that were not known at the time of the previous classification. After the publication of Smith and Patton (1999) two new extant genera, Handleyomys (Voss et al., 2002) and Tapecomys (Anderson and Yates, 2000), were erected. In addition, Deltamys was granted rank of genus (D’Elía et al., in press a). Amphinectomys described by Malygin et al. (1994) was not listed in Smith and Patton (1999). Finally, it must be pointed out that McKenna and Bell (1997) included in the Sigmodontinae three other tribes: Neotomini, Peromyscini, and Tylomyini. Reig (1986) and Smith and Patton (1999) explicitly excluded these groups from Sigmodontinae. 
Moreira, 2001; Myers et al., 1995; Steppan, 1998), among a few presumably related genera (e.g., Apfelbaum and Reig, 1989; Barrantes et al., 1993; Chiappero et al., 2002; Patton et al., 1989; Smith and Patton, 1991, 1993), small parts of the sigmodontine radiation (e.g., Anderson and Yates, 2000), or had a reduced sampling of sigmodontines (e.g., Engel et al., 1998). Therefore, most studies were not designed to test neither the monophyly of the recognized suprageneric groups (tribes) nor the relationships among them. The exceptions were the studies of Steppan (1995), Smith and Patton (1999), D’Elía et al. (in press a, in press b), and Weksler (in press) which included a broad representation of sigmodontine diversity and thus constituted the main attempts to assess sigmodontine phylogenetic relationships with an explicit phylogenetic approach. Not surprisingly, in many aspects the results of these studies departed from traditional views of sigmodontine systematics. This is particularly true of Smith and Patton (1999) regarding the limits and contents of most tribes. Smith and Patton's (1999) study as well as those of D'Elía et al. (in press a, in press b) were based on cytochrome $b$ gene sequences, which constitute by far the most commonly used source of evidence in mammal molecular phylogenetics. Weksler's (in press) study was based on nuclear sequences of the interphotoreceptor retinoid binding protein (IRBP) gene.

In this contribution I present a hypothesis of sigmodontine phylogenetic relationships based on mitochondrial and nuclear DNA sequences. Although the relationships among non-akodont taxa are considered, special attention is drawn to the testing of hypotheses concerning the limits of that group, its placement within the sigmodontine radiation, and the relationships among its taxa. I present some taxonomic judgments based on the resulting phylogeny. Finally, I comment on the historical biogeography of sigmodontines in the light of the newly uncovered relationships. This study is the first to combine nuclear and mitochondrial DNA sequences in order to investigate sigmodontine phylogenetics.

\section{Materials and methods}

\section{Taxonomic sampling}

Since sigmodontine rodents are highly diverse (there are around 71 extant genera; modified from Musser and Carleton, 1993) inclusion of all taxa in a single study is currently not feasible. In order to decide which taxa would be included in this study, I relied on traditional systematic studies (e.g., Hershkovitz, 1966; Reig, 1980) and previous phylogenetic analyses (D'Elía et al., in press a, in press b; Engel et al., 1998; Smith and Patton, 1999) to insure that sigmodontine diversity was repre- sented as thoroughly as possible. This study includes a total of 68 sigmodontine specimens currently grouped in 57 species that represent 35 taxa usually ranked at the generic level. This sample lacked one of the recognized sigmodontine groups (the tribe Ichthyomyini) as well as several genera previously considered as incertae sedis by different authors. As the study is focused on the akodont group, taxonomic coverage is particularly broad with regards to taxa that at some point in sigmodontine taxonomic history have been considered to be akodonts, for which, when possible, more than one species per genus was included. Finally, for several sigmodontine species more than one individual per species was included to assess levels of intraspecific variation. Specimens included in the study are listed in Table 2.

Although sigmodontine (sensu Reig, 1980) monophyly is well corroborated (Dickerman, 1992; Engel et al., 1998; D'Elía and Weksler in prep.; but see also Steppan, 1995) the identity of its sister group is not clear. Sigmodontinae forms part of a large cricetid clade composed of other main branches of the muroid radiation (Dickerman, 1992; D'Elía and Weksler in prep; see also D'Elía, 2000). Currently, the relationships among those groups are not clear. Therefore, to polarize sigmodontine character states, I have included outgroups (Nixon and Carpenter, 1993) that are representative of each of the other primary clades that make up the large cricetid clade. These are the arvicolines (of which the genus Arvicola was included), the cricetines (Cricetus), the neotomines (Neotoma), the peromyscines (Peromyscus, Onychomys, and Reithrodontomys), the tylomyines (Tylomys), and the genus Scotinomys. In addition, the genus Baiomys, presumably related to Scotinomys but whose phylogenetic placement within the cricetid radiation is not clear (McKenna and Bell, 1997), was also included as an outgroup.

\section{Sequence data}

The first $1134 \mathrm{bp}$ of the cytochrome $b$ gene (hereafter cyt $b$ ) and a fragment of $759 \mathrm{bp}$ of the first exon of the nuclear gene interphotoreceptor retinoid binding protein (hereafter IRBP) were used as evidence. In all cases, for each terminal, both mitochondrial and nuclear sequences were generated from the same individual; i.e., no chimerical terminal was created. Some of the cyt $b$ sequences employed were generated within the framework of the present study, some were taken from D'Elía et al. (in press b), some were kindly provided by Dr. James L. Patton (Museum of Vertebrate Zoology), and some were retrieved from GenBank. The source of each cyt $b$ sequence is presented in Table 2. All IRPB sequences were generated here.

Cyt $b$ sequences reported in this study were amplified and sequenced in two fragments using the primer pairs MVZ 05-MVZ 16 and MVZ 103-MVZ 14, which are 
Table 2

List of specimens used in the phylogenetic analysis

\begin{tabular}{|c|c|c|c|}
\hline & Taxon & Catalog no. ${ }^{\mathrm{a}}$ & Cyt $b$ source $^{\mathrm{b}}$ \\
\hline \multicolumn{4}{|c|}{ Ingroup } \\
\hline 1 & Abrothrix andinus & MVZ 174066 & AF108671 \\
\hline 2 & A. longipilis & MVZ 154494 & U03530 \\
\hline 3 & A. olivaceus & MVZ 155753 & AF027320 \\
\hline 4 & A. olivaceus & UP TR-004 & * \\
\hline 5 & Akodon azarae & GD 264 & \# \\
\hline 6 & A. dolores & UP PY16 & $*$ \\
\hline 7 & A. iniscatus & MVZ 182655 & JLP \\
\hline 8 & A. mimus & MVZ 171512 & JLP \\
\hline 9 & A. montensis & UMMZ 174969 & $*$ \\
\hline 10 & A. montensis & MN 48066 & $*$ \\
\hline 11 & A. mystax & MN 48070 & $*$ \\
\hline 12 & A. siberiae & NK 12081 & $*$ \\
\hline 13 & A. spegazzinii & UP AC-008 & AY196165 \\
\hline 14 & A. torques & MVZ 171720 & M35700 \\
\hline 15 & A. varius & TK 66486 & $*$ \\
\hline 16 & "Akodon" serrensis & VA 1 & $*$ \\
\hline 17 & Auliscomys pictus & MVZ 172700 & U03545 \\
\hline 18 & Bibimys chacoensis & UP CL001 & \# \\
\hline 19 & B. labiosus & MN 62062 & $\#$ \\
\hline 20 & Blarinomys breviceps & CIT 1391 & $*$ \\
\hline 21 & Brucepattersonius igniventris & MVZ 183250 & AF108667 \\
\hline 22 & B. soricinus & MVZ 186036 & JLP \\
\hline 23 & Calomys callosus & GD 421 & $*$ \\
\hline 24 & Chelemys macronyx & MVZ 155800 & U03533 \\
\hline 25 & "Chroeomys" jelskii & MVZ 173076 & * \\
\hline 26 & Delomys sublineatus & MVZ 183075 & AF108687 \\
\hline 27 & Deltamys kempi & MNHN 4151 & AY195862 \\
\hline 28 & Eligmodontia typus & MVZ 182681 & AF 108692 \\
\hline 29 & Euneomys chinchilloides & UP LB018 & $*$ \\
\hline 30 & Geoxus valdivianus & UP CAV001 & $*$ \\
\hline 31 & G. valdivianus & MVZ 154601 & U03531 \\
\hline 32 & Graomys griseoflavus & UP 278 & * \\
\hline 33 & Irenomys tarsalis & MVZ 155869 & U03534 \\
\hline 34 & Juliomys pictipes & MVZ 182079 & * \\
\hline 35 & Juscelinomys huanchacae & LHE 1616 & $*$ \\
\hline 36 & J. huanchacae & LHE 1617 & * \\
\hline 37 & Kunsia tomentosus & LHE 1619 & * \\
\hline 38 & K. tomentosus & LHE 1620 & $*$ \\
\hline 39 & Lenoxus apicalis & MVZ 171752 & U03541 \\
\hline 40 & Loxodontomys micropus & UP EPU001 & $*$ \\
\hline 41 & Necromys amoenus & MVZ 171569 & * \\
\hline 42 & N. lasiurus & TK 64302 & * \\
\hline 43 & N. temchuki & UP 223 & $*$ \\
\hline 44 & N. temchuki & UP 022 & $*$ \\
\hline 45 & N. urichi & AMNH 257281 & JLP \\
\hline 46 & N. urichi & AMNH 257287 & JLP \\
\hline 47 & Oryzomys megacephalus & GD 463 & $*$ \\
\hline 48 & Oecomys superans & MVZ 155006 & $*$ \\
\hline 49 & Oxymycterus delator & UMMZ 175101 & $*$ \\
\hline 50 & O. hiska & MVZ 171518 & U03542 \\
\hline 51 & O. nasutus & MVZ 182701 & JLP \\
\hline 52 & O. rufus & UP AC04 & $*$ \\
\hline 53 & O. rufus & UP 33 & * \\
\hline 54 & Phyllotis xanthopygus & UP 111 & * \\
\hline 55 & Reithrodon auritus & MLP 26.VIII.01.17 & $*$ \\
\hline 56 & $R$. auritus & MVZ 182707 & AF108694 \\
\hline 57 & Rhipidomys macconnelli & MVZ 160082 & * \\
\hline 58 & Scapteromys aquaticus & UP BAL509 & * \\
\hline 59 & S. aquaticus & UMMZ 174991 & $*$ \\
\hline 60 & S. tumidus & MVZ 193269 & $*$ \\
\hline 61 & Scolomys juruaense & MVZ 194268 & AF108696 \\
\hline 62 & Sigmodon hispidus & NK 27055 & AF 155418 \\
\hline
\end{tabular}


Table 2 (continued)

\begin{tabular}{|c|c|c|c|}
\hline & Taxon & Catalog no. ${ }^{a}$ & Cyt $b$ source $^{\mathrm{b}}$ \\
\hline 63 & Thalpomys cerradensis & MZUSP 30400 & $*$ \\
\hline 64 & T. cerradensis & MZUSP 30397 & $*$ \\
\hline 65 & Thaptomys nigrita & MVZ 183044 & AF108666 \\
\hline 66 & Thomasomys aureus & MVZ 170076 & U03540 \\
\hline 67 & T. ischyurus & MVZ 181999 & AF108675 \\
\hline 68 & Wiedomys pyrrhorhinus & MVZ 197567 & $*$ \\
\hline \multicolumn{4}{|c|}{ Outgroup } \\
\hline 69 & Arvicola terrestris & MVZ 155884 & $*$ \\
\hline 70 & Baiomys taylori & NK 3696 & $*$ \\
\hline 71 & B. taylori & NK 20393 & $*$ \\
\hline 72 & Cricetus cricetus & MVZ 155880 & $*$ \\
\hline 73 & Neotoma albigula & MVZ 147667 & AF108704 \\
\hline 74 & Onychomys torridus & MVZ 196051 & $*$ \\
\hline 75 & Peromyscus truei & MVZ 157329 & AF108703 \\
\hline 76 & Reithrodontomys megalotis & MVZ 148519 & AF108707 \\
\hline 77 & Scotinomys teguina & MVZ 191230 & AF108705 \\
\hline 78 & S. xerampelinus & MVZ 192158 & AF108706 \\
\hline 79 & Tylomys sp. & USNM 464887 & $/ /$ \\
\hline
\end{tabular}

Their catalog number and the source of their cyt $b$ sequences are indicated. All IRBP sequences were generated in this study.

${ }^{a}$ Voucher specimens are, or will be, catalogued in the following museum collections: Already catalogued. Argentina: MLP, Museo de La Plata, Universidad Nacional de la Plata. Brazil: MN, Museu Nacional, Rio de Janeiro; MZUP, Museu de Zoologia da Universidade de São Paulo. United States of America: AMNH, American Museum of Natural History; NK, Museum of Southwestern Biology, University of New Mexico; MVZ, Museum of Vertebrate Zoology, University of California at Berkeley; USNM, National Museum of Natural History; TK, The Museum of Texas Tech University; UMMZ, The University of Michigan Museum of Zoology. Uruguay: MNHN, Museo Nacional de Historia Natural. To be catalogued. Argentina: UP (collected by Ulyses F.J. Pardiñas), Museo de La Plata, Universidad Nacional de La Plata. Brazil: VA (collected by Lena Geise), Museu Nacional, Rio de Janeiro; CIT (Laboratório de Citogenética de Vertebrados, Instituto de Biociências, Universidade de São Paulo), Museu de Zoologia da Universidade de São Paulo. Paraguay: GD (collected by Guillermo D’Elía), Museo Nacional de Historia Natural del Paraguay. United States of America: LHE (collected by Louise Emmons), National Museum of Natural History.

${ }^{\mathrm{b}}$ The source of the cyt $b$ sequences used is the following: numbers refer to GenBank accession numbers: *, sequences generated in this study; JLP, sequences provided by James L. Patton, Museum of Vertebrate Zoology; \#, taken from D'Elía et al. (in press b); //, taken from D’Elía and Weksler in preparation.

located both internally and in the flanking regions of the gene (da Silva and Patton, 1993; Smith pers. com.). Cyt $b$ sequences were amplified using the following protocol: $94^{\circ} \mathrm{C}$ for $3 \mathrm{~min}$; 33 cycles of denaturation at $94^{\circ} \mathrm{C}$ for $20 \mathrm{~s}$, annealing at $48^{\circ} \mathrm{C}$ for $15 \mathrm{~s}$ and extension at $72^{\circ} \mathrm{C}$ for $60 \mathrm{~s} ; 72^{\circ} \mathrm{C}$ for $7 \mathrm{~min}$. IRBP sequences were amplified and sequenced in one fragment using the primers $\mathrm{A} 1$ and $\mathrm{F} 1$; the exception being Delomys for which the primers A and $F$ were used. All primers are located internally to the first IRBP exon and were reported by Jansa and Voss (2000). IRBP sequences were amplified, following Jansa and Voss (2000), using a touchdown protocol with four stages. The first stage consisted of five cycles of denaturation at $95^{\circ} \mathrm{C}$ for $20 \mathrm{~s}$, annealing at $58^{\circ} \mathrm{C}$ for $15 \mathrm{~s}$ and extension at $72^{\circ} \mathrm{C}$ for $60 \mathrm{~s}$. For the second and third stages the annealing temperature was changed to 56 and $54{ }^{\circ} \mathrm{C}$, respectively. The final stage consisted of 23 cycles at $52{ }^{\circ} \mathrm{C}$ of annealing temperature. Amplification reactions started with a DNA denaturation at $95^{\circ} \mathrm{C}$ for 10 min and ended with a DNA extension at $72^{\circ} \mathrm{C}$ for $7 \mathrm{~min}$. Negative controls were included in all cyt $b$ and IRBP experiments. Amplification products excised from an electrophoresis gel were purified using a QIAamp gel extraction kit (Qiagen). Purified products were sequenced in both directions with the amplification primers and dye-labelled nucleotides (Big Dye, Applied Biosystems). Sequencing reactions were cleaned in Sephadex (Sigma) columns and run in an ABI 377 automated sequencer. In all cases, both heavy and light DNA strands were sequenced. Sequences of both strands were reconciled using Sequencer Navigator version 1.0.1 (Applied Biosystems). All sequences were deposited in GenBank (AY273904-AY273919, AY275106-AY275134, and AY277407-AY277486).

\section{Phylogenetic analyses}

Sequence alignment was carried out with the program Clustal X (Thompson et al., 1997), by using the default values for all alignment parameters. A gap of $3 \mathrm{bp}$ was inserted in the IRBP sequence of Baiomys. Since species diversifications are necessarily unique events that have already occurred (Kluge, 2002), no probabilistic approach was used to reconstruct them; aligned sequences were subjected to maximum parsimony analysis (MP; Farris, 1982; Kluge and Farris, 1969). In all cases characters were treated as unordered and equally weighted. Gaps were treated as missing data and as a fifth state (i.e., two rounds of searches were conducted). PAUP* 4 (Swofford, 2000) was used to perform 200 
replicates of heuristic searches with random addition of sequences and tree bisection-reconnection branch swapping. Two measures of topology support were carried out. First, 1000 parsimony jackknife replications (JK; Farris et al., 1996) with five addition sequence replicates each and the deletion of one third of the character data were performed. Branches with less than $50 \%$ of support were allowed to collapse. Second, regular Bremer support values (BS; Bremer, 1994) and partitioned Bremer support values (PBS; a measure of the positive or negative contribution of each partition to the character support for a particular node in the simultaneous analysis, Baker and De Salle, 1997) were computed for each node in PAUP* using command files written in TreeRot version 2 (Sorenson, 1999).

Systematists have long debated whether logically separable data sets can be drawn from different sources of the same taxa (e.g., different DNA fragments, DNA and morphological data) and have also debated on the appropriateness of analyzing these different datasets separately or in combination (Bull et al., 1993; de Queiroz et al., 1995; De Salle and Brower, 1997; Eernisse and Kluge, 1993; Huelsenbeck et al., 1996; Kluge, 1989; Miyamoto and Fitch, 1995; Nixon and Carpenter, 1996; Siddall, 1997). This study is based on the simultaneous analyses of both genes. To detect the presence of character conflict between both gene partitions I computed the incongruence length difference (ILD) test as described by Farris et al. $(1994,1995)$ and implemented in WINCLADA version 0.9.9+ (BETA) (Nixon, 1999). See Baker and Lutzoni (2002) for a recent examination of the interpretation of the ILD as a test of data combinability.

Finally, the number of unambiguous changes per gene and codon position were documented by examining PAUP* outputs. Only those changes unambiguously optimized irrespective of the kind of character transformation used (i.e., accelerated: ACCTRAN or delayed: DELTRAN) were taken into account.

\section{Results}

\section{Sequence description}

Cytochrome $b$ haplotypes show a strong base compositional bias, with a marked deficit of guanine, especially in third positions (Table 3). Cytochrome $b$ haplotypes are defined by 517 variables sites; of which 120 correspond to first codon positions, 41 to second positions, and 356 to third positions. IRBP alleles show an overall even pattern of base composition (Table 3 ). There are 140 variable sites in the IRPB sequences, of which 28 correspond to first codon positions, 17 to second positions, and 95 to third positions. Levels of observed variation of both genes at different hierarchical levels are summarised in Table 4.
Table 3

Summary of base composition of 68 sigmodontine specimens

\begin{tabular}{llllll}
\hline & & $\mathrm{A}$ & $\mathrm{C}$ & $\mathrm{G}$ & $\mathrm{T}$ \\
\hline Cyt $b$ & Total & 0.29 & 0.29 & 0.12 & 0.30 \\
& First & 0.31 & 0.24 & 0.21 & 0.24 \\
& Second & 0.21 & 0.25 & 0.12 & 0.42 \\
& Third & 0.36 & 0.38 & 0.03 & 0.23 \\
& & & & \\
IRBP & Total & 0.23 & 0.28 & 0.28 & 0.21 \\
& First & 0.25 & 0.28 & 0.34 & 0.13 \\
& Second & 0.28 & 0.21 & 0.19 & 0.32 \\
& Third & 0.16 & 0.33 & 0.30 & 0.21 \\
\hline
\end{tabular}

\section{Phylogeny}

The topologies obtained from the analysis of both gap-handling schemes are the same. Therefore, I present only the results of those analyses in which gaps were treated as missing data. The combined dataset has 902 variable characters of which 748 are parsimony informative. Two most parsimonious cladograms resulted from the analysis of this dataset. The trees are 7410 steps in length. They have an ensemble consistency index (CI) of 0.199 and a retention index (RI) of 0.523 . The strict consensus tree (Nelson, 1979) defines 75 nodes of which 66 belong to the sigmodontine clade (Fig. 1). Support for these nodes is highly variable. In the jackknife analysis, 22 nodes, of which 19 correspond to the sigmodontine clade, collapse at the cut off of $50 \%$. Bremer support values range from 1 to 72 .

Sigmodontinae (Fig. 1A, node 66) appears to be well supported with a jackknife support value (JK) of $100 \%$, and a Bremer support index (BS) of 14. Relationships within the sigmodontine clade are well resolved with the existence of only one polytomy that involves species of Necromys. However, several of these clades are weakly supported, thus collapsing in the jackknife analysis to create a large basal polytomy. This polytomy includes: (a) several monogeneric lines (Delomys, Euneomys, Juliomys, Reithrodon, Sigmodon, Thomasomys, and Wiedomys), (b) a clade formed by Irenomys, Scolomys, and Rhipidomys (node 56), and (c) clades corresponding to recognized sigmodontines groups of genera (e.g., akodontines, abrothricines, oryzomyines, and phyllotines). Among these groups, the phyllotine tribe (node 43) is the one with the weakest support $(\mathrm{JK}=54, \mathrm{BS}=5)$ and the abrothricine group (node 53) has the strongest support $(\mathrm{JK}=98, \mathrm{BS}=7)$. Akodontini sensu Smith and Patton (1999) (node 38) also constitutes a well-supported natural group $(\mathrm{JK}=97 \%$, $\mathrm{BS}=6$ ).

Gene congruence and contribution to the general topology

The ILD test revealed that the amount of character conflict between both genes is not significant $(P=0.999)$. PBS values indicate that 28 of the 75 clades 
Table 4

Ranges of observed sequence divergence among sampled sigmodontines at different hierarchical levels

\begin{tabular}{llllll}
\hline & \multicolumn{2}{l}{ Same species } & & \multicolumn{2}{l}{ Different species } \\
\cline { 2 - 3 } \cline { 5 - 6 } & Same population & Different population & & Same genus & Different genus \\
\hline Cyt $b$ & $0.18-0.53$ & $0.26-11.37$ & $1.23-14.72$ & $9.26-24.34$ \\
IRBP & 0 & $0-0.26$ & $0-1.71$ & $0.79-9.88$ \\
\hline
\end{tabular}

Note. See Table 2 for the list of specimens, species and genera on which these comparisons are based. Intrapopulation comparisons were based on specimens of Juscelinomys huanchacae, Kunsia tomentosus and Thalpomys cerradensis. Interpopulation comparisons were based on specimens of Abrothrix olivaceus, Akodon montensis, Geoxus valdivianus, Necromys temchuki, N. urichi, and Oxymycterus rufus.

are supported by characters from both cyt $b$ and IRBP genes (i.e., PBS values are positive for both genes). In addition, five clades, which are supported by cyt $b$ substitutions, are neither contradicted nor supported by the IRBP evidence (i.e., IRPB PBS=0). Thirty-eight clades are supported by cyt $b$ characters and contradicted by the evidence from IRBP (i.e., IRBP negative PBS values). Finally, only four clades of the combined analysis are contradicted by characters of the cyt $b$ gene. Overall, in the combined analysis cyt $b$ characters support a total of 71 clades; meanwhile IRBP characters support 32 nodes (Table 5). The resolution at the base of the sigmodontine radiation, at the base of the akodontine clade, and among Akodon species shown in the simultaneous topology is mostly provided by cyt $b$ gene characters.

Finally, consistency and retention indices for each gene, as well as for each codon position of each gene were also computed over the simultaneous analysis (Table 6). These measures indicate that cyt $b$, in comparison with IRBP, is more homoplastic (smaller CI) and contributes fewer synapomorphies to the most parsimonious trees (smaller RI). According to the most parsimonious trees, each of the cyt $b$ and IRBP informative characters changed state 12.35 and 3.3 times, respectively. When state changes are calculated for each codon position, IRBP informative characters changed with roughly the same frequency at each position, averaging $3.11,4.60$, and 3.13 state changes for first, second, and third positions, respectively. In contrast, the number of state changes per informative character is not evenly distributed across cyt $b$ codon positions. Informative changes located in third codon positions, which account for $67 \%$ of the informative characters for cyt $b$ and $48.0 \%$ for the complete dataset, have evolved much faster (14.69 substitutions on average) than the informative characters from first and second positions (12.35 and 8.31 times each respectively).

\section{Discussion}

It has been more than a decade since the phylogenetic relationships among sigmodontine taxa were first studied with an explicitly phylogenetic approach. Most of these studies were based on the analysis of mitochon- drial DNA sequences, although other sources of evidence have also been explored (e.g., morphology, karyotypes, allozymes, DNA/DNA hybridization). Data have been analyzed using maximum parsimony under a diversity of weighting schemes, maximum likelihood under a variety of evolutionary models, and also with distance algorithms involving different genetic distances. The use of different analytical methods makes it hard to directly compare results from these studies with those of the present research (Brower et al., 1996). Among these studies, the one of Smith and Patton (1999) deserves to be singled out for two reasons. First, its broad taxonomic coverage allowed testing of most of the traditional sigmodontine suprageneric groups, resulted in novel historical hypotheses and a new classificatory scheme. Second, it provided a main hypothesis that could be used to frame additional studies (e.g., D'Elía et al., in press b; Emmons, 1999).

Early in sigmodontine taxonomy, genera were arranged into groups. Some of these groups were later formalized into tribes (e.g., Akodontini, Phyllotini) while others were not (e.g., oxymycterine group). The identity and contents of these groups have been the center of much discussion, and their content has fluctuated from author to author (see examples in Table 1). I have included representatives of all traditional groups, with the sole exception of the ichthyomyines (Ichthyomyini). In addition, I have included some genera traditionally considered to be well-differentiated sigmodontine lines (e.g., Wiedomys), or whose phylogenetic relationships have been center of much debate through taxonomic history (e.g., Reithrodon), or that have been recently called into question due to results of phylogenetic analysis (e.g., Bibimys).

The present study is the first one to deal with sigmodontine phylogenetics by combining characters from the mitochondrial and the nuclear genomes. The combined analyses retrieved two shortest trees of 7410 steps in length. Their consensus is a well-resolved cladogram, although clades show a wide range of support (Fig. 1 and Table 5). Because of the broad taxonomic coverage of this study, the complex taxonomic history of the study group, several features of the consensus tree deserve discussion. However, I shall concentrate here mainly on relationships among akodontine taxa. I also comment on other genera that have played a relevant 


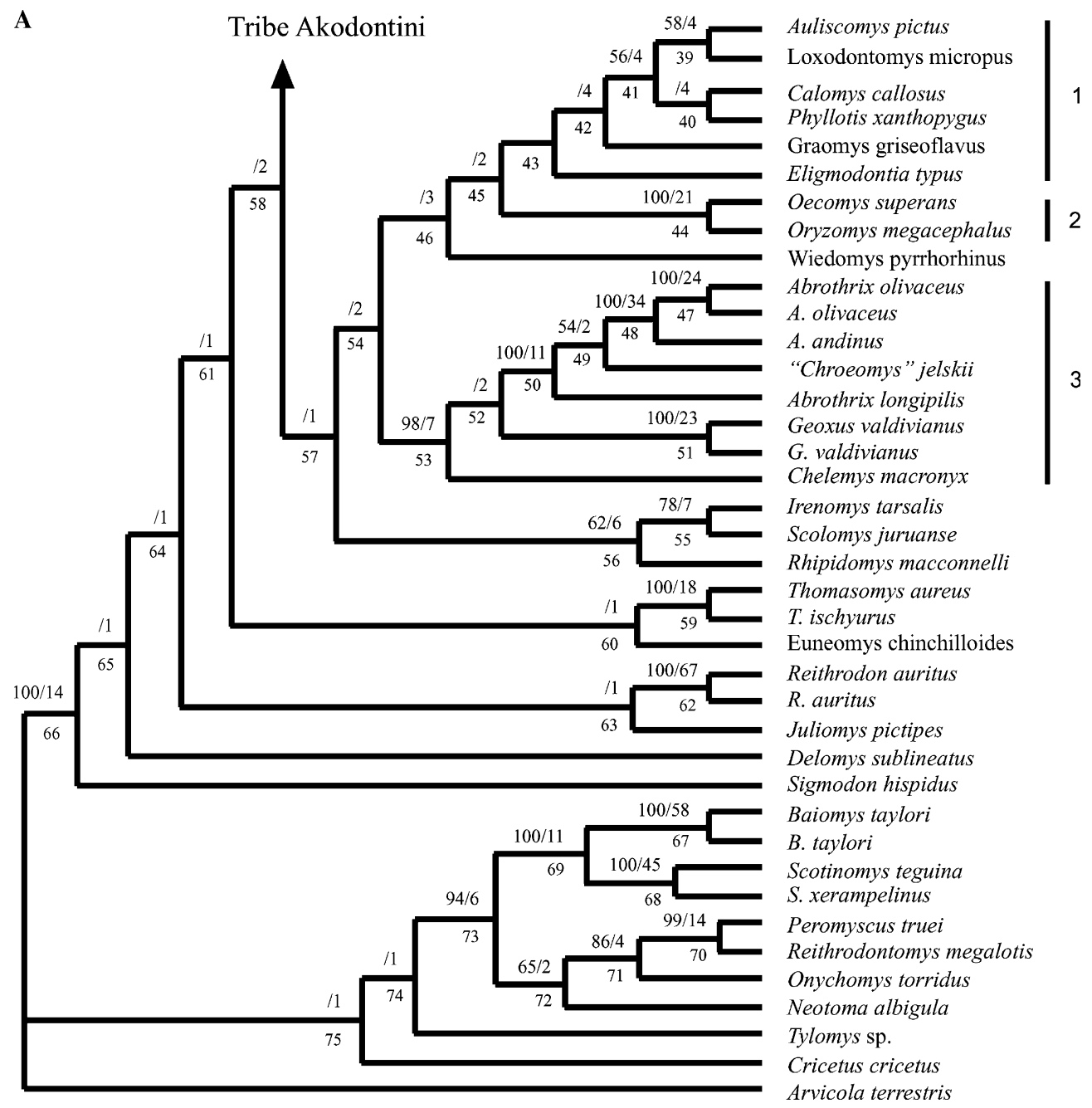

Fig. 1. Strict consensus tree of the two most parsimonious trees (length $7410, \mathrm{CI}=0.199, \mathrm{RI}=0.523$ ) obtained in the maximum parsimony analysis of 68 sigmodontine and 11 outgroup specimens. Numbers above branches indicate parsimony jackknife (left of the diagonal) and Bremer support (right to the diagonal) values of the nodes at their right. Only jackknife values above $50 \%$ are shown. Numbers below branches identify nodes at their right. Node numbers are cited in the main text and in Tables 5 and 7. (A) Details of the consensus tree corresponding to the outgroup taxa and the sigmodontine clade less the akodontine tribe. 1, Phyllotini; 2, Oryzomyini; 3, abrothricine group. (B) Part of the consensus tree corresponding to Akodontini. Bars A-E identify clades that are discussed in the text.

role through sigmodontine taxonomic history and evolutionary studies. Following the consensus tree I have structured this section into four parts.

\section{The sigmodontine basal radiation}

The most basal dichotomy within the sigmodontine clade leads to Sigmodon on one hand and to a clade composed of all other sigmodontines on the other (Fig. 1A). The node at the base of the "all sigmodontines less Sigmodon" clade is weakly supported $(\mathrm{JK}<50 \%$; BS $=1$; PBS details in Table 5 node 65$)$ indicating that the hypothesis of Sigmodon being the sister of the rest of the sigmodontines is not well supported by the simultaneous analysis of cyt $b$ and IRBP characters. However, the position of Sigmodon as sister to the reaming sigmodontines is corroborated in a broad study based on cyt $b$ sequences (D'Elía et al., in press a) and in a more reduced phylogenetic analysis of four other mitochondrial genes (Engel et al., 1998). This finding is important on two accounts. First, it corroborates that Sigmodon is the sole living member of the tribe Sigmodontini, implying that an S-shaped third molar has evolved independently more than once (e.g., Euneomys, Holochilus, and Reithrodon) within the sigmodontine radiation. Second, the fact that Sigmodon is the sister group of the remaining sigmodontines has direct implications for the study of sigmodontine historical biogeography, a topic to be covered below.

Basal relationships within the "all sigmodontines less Sigmodon" clade are mostly defined by cyt $b$ characters (Table 7). This part of the tree is weakly supported; in the jackknife analysis 10 basal nodes collapse at the $50 \%$ 


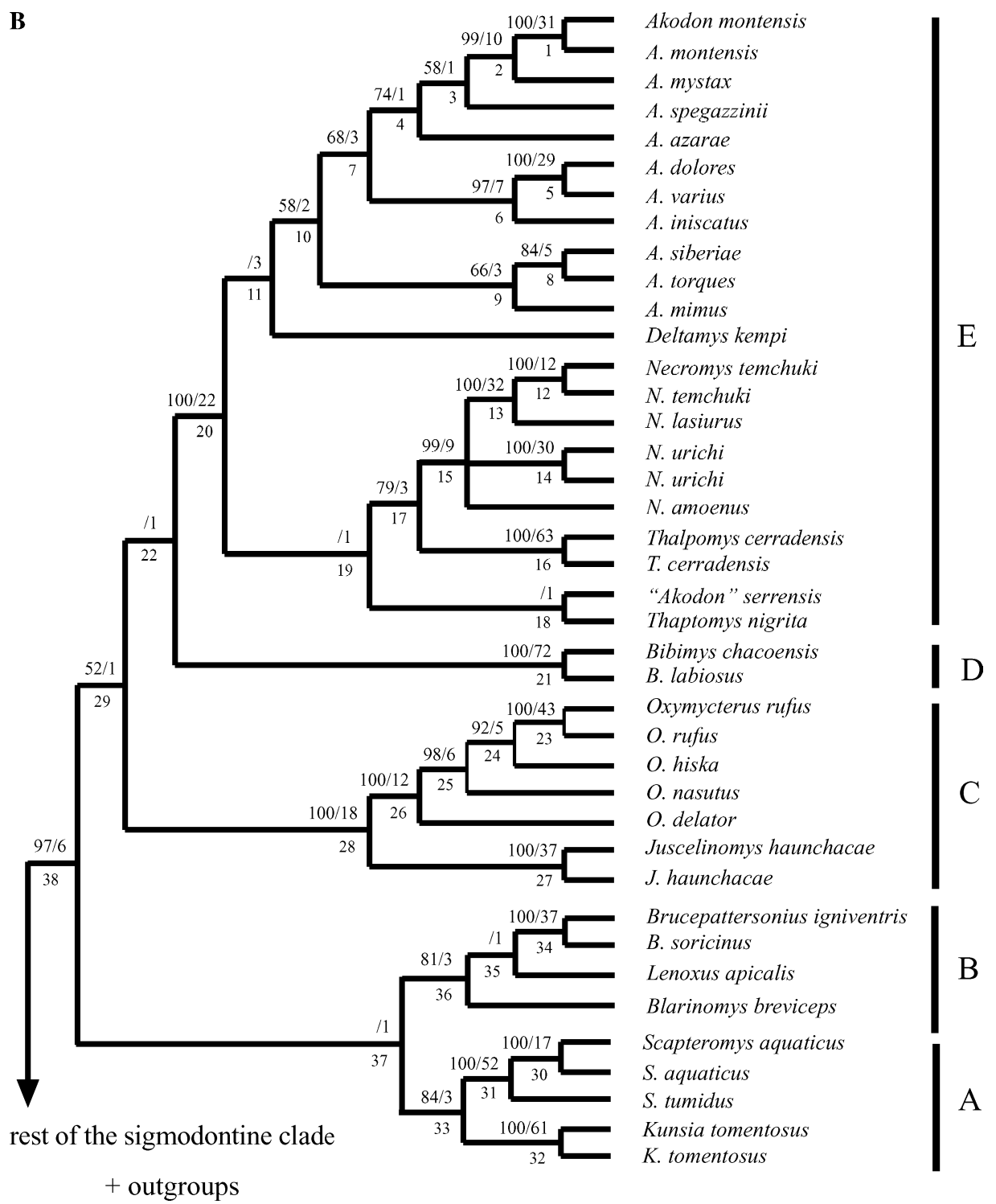

Fig. 1. (continued)

cut off, generating a large basal polytomy encompassing 12 sigmodontine clades. Seven of these 12 clades, including the one made up of Sigmodon, are monogeneric, four other clades are groups of genera that correspond more or less to classic sigmodontine tribes, and the last one is formed by Irenomys, Scolomys, and Rhipidomys. This last clade (node 56 in Fig. $1 \mathrm{~A}$; $\mathrm{JK}=62, \mathrm{BS}=6$ ) is only supported by cyt $b$ characters and has not been recovered in any previous phylogenetic analysis. Scolomys and Rhipidomys are traditionally placed in the oryzomyine and thomasomyine tribes, respectively (see below). Irenomys has been placed in the phyllotine tribe (Braun, 1993; Olds and Anderson, 1989), as well explicitly excluded from it (Hershkovitz, 1962).

One of the recovered clades (node 43 in Fig. 1A; $\mathrm{JK}=54, \mathrm{BS}=5$ ) comprises the phyllotines, Auliscomys, Calomys, Eligmodontia, Graomys, Loxodontomys, and
Phyllotis, but not the genera Euneomys, Irenomys, or Reithrodon, all of which have been considered phyllotines by several authors (e.g., McKenna and Bell, 1997; Steppan, 1995). Smith and Patton (1999) have already presented evidence to exclude Reithrodon and Irenomys from the phyllotine clade. Their conclusion is here expanded with regard to the Euneomys. Forty-four additional steps are needed to recover a clade formed by all traditionally recognized "phyllotine" genera; while 23, 27 , or 15 additional steps are needed to place respectively Euneomys, Irenomys, or Reithrodon in the phyllotine clade.

In their contribution, when dealing with the diagnosis of the phyllotine tribe, Olds and Anderson (1989) identified a group of three living genera (Euneomys, Neotomys, and Reithrodon) on the basis of several morphological characters for which the informal name 
Table 5

Partitioned bremer support values for each gene

\begin{tabular}{|c|c|c|c|c|c|c|c|c|c|c|c|c|c|c|}
\hline PBS IRBP & 1.2 & 2.5 & 0 & 0 & 1 & -2.5 & 3.5 & 0.5 & 3.5 & 3.5 & -0.5 & -0.5 & 1.5 & 0.5 \\
\hline PBS Cyt $b$ & 29.8 & 7.5 & 1 & 1 & 28 & 9.5 & -0.5 & 4.5 & -0.5 & -1.5 & 3.5 & 12.5 & 30.5 & 29.5 \\
\hline Node & 1 & 2 & 3 & 4 & 5 & 6 & 7 & 8 & 9 & 10 & 11 & 12 & 13 & 14 \\
\hline PBS IRBP & 1.5 & 5 & -2 & 0.5 & 0.5 & 1 & 11.1 & -2.5 & 3 & 0 & -0.5 & -3.5 & -0.5 & 2 \\
\hline PBS Cyt $b$ & 7.5 & 58 & 5 & 0.5 & 0.5 & 21 & 60.9 & 3.5 & 40 & 5 & 6.5 & 15.5 & 37.5 & 16 \\
\hline Node & 15 & 16 & 17 & 18 & 19 & 20 & 21 & 22 & 23 & 24 & 25 & 26 & 27 & 28 \\
\hline PBS IRBP & -2.5 & -2.5 & 8 & 5.5 & -1 & -1 & -0.8 & 2 & -2.5 & -2 & -4.5 & -4.5 & -4.5 & -4.5 \\
\hline PBS Cyt $b$ & 3.5 & 19.5 & 44 & 55.5 & 4 & 38 & 1.8 & 1 & 3.5 & 8 & 8.5 & 8.5 & 8.5 & 8.5 \\
\hline Node & 29 & 30 & 31 & 32 & 33 & 34 & 35 & 36 & 37 & 38 & 39 & 40 & 41 & 42 \\
\hline PBS IRBP & 3.5 & 6.5 & -4.6 & -8 & 3.5 & 3 & 3 & 2 & -1.5 & -4.5 & 5 & -4.7 & -5 & 0 \\
\hline PBS Cyt $b$ & 1.5 & 14.5 & 6.6 & 11 & 20.5 & 31 & -1 & 9 & 24 & 6.5 & 2 & 6.7 & 12 & 6 \\
\hline Node & 43 & 44 & 45 & 46 & 47 & 48 & 49 & 50 & 51 & 52 & 53 & 54 & 55 & 56 \\
\hline PBS IRBP & -2.5 & -5.4 & -2 & -6 & -6 & 12 & -6 & -3 & -6 & 6.9 & 8.5 & 11 & 9 & -2 \\
\hline PBS Cyt $b$ & 3.5 & 7.4 & 20 & 7 & 7 & 55 & 7 & 4 & 7 & 7.1 & 49.5 & 34 & 2 & 16 \\
\hline Node & 57 & 58 & 59 & 60 & 61 & 62 & 63 & 64 & 65 & 66 & 67 & 68 & 69 & 70 \\
\hline PBS IRBP & 0 & -2 & -5.1 & -6 & -6 & & & & & & & & & \\
\hline PBS Cyt $b$ & 4 & 10 & 11.1 & 7 & 7 & & & & & & & & & \\
\hline Node & 71 & 72 & 73 & 74 & 75 & & & & & & & & & \\
\hline
\end{tabular}

Note. Node numbers correspond to those indicated in Fig. 1.

Table 6

Indices for site class of each of the two gene partitions

\begin{tabular}{|c|c|c|c|c|c|}
\hline Site class & & $n$ & Steps & $\mathrm{CI}$ & RI \\
\hline Simultaneous & & 748 & 7410 & 0.199 & 0.523 \\
\hline \multirow[t]{4}{*}{ Cyt $b$} & Total & 546 & 6743.5 & 0.163 & 0.500 \\
\hline & First & 129 & 1072.5 & 0.229 & 0.545 \\
\hline & Second & 51 & 294 & 0.330 & 0.676 \\
\hline & Third & 366 & 5377 & 0.140 & 0.478 \\
\hline \multirow[t]{4}{*}{ IRBP } & Total & 202 & 666.5 & 0.566 & 0.750 \\
\hline & First & 44 & 137 & 0.635 & 0.772 \\
\hline & Second & 24 & 110.5 & 0.434 & 0.664 \\
\hline & Third & 134 & 419 & 0.578 & 0.765 \\
\hline
\end{tabular}

Note. Indices were calculated from the two most parsimonious hypotheses resulting from the simultaneous analysis. First, second and third refer to codon position. $n$, number of parsimony informative sites; Steps, mean length on the two most parsimonious trees; CI, consistency index; $\mathrm{RI}$, retention index.

Reithrodon-group was coined (see also Braun, 1993; Steppan, 1995). Later, Pardiñas (1997), Steppan and Pardiñas (1998), and Ortiz et al. (2000) expanded this group with the inclusion of extinct taxa. I have included two of the three living members of the Reithrodongroup, Reithrodon and Euneomys. These two genera are not sister to each other. Reithrodon appears as sister to Juliomys (node 63), and Euneomys appears as sister to Thomasomys (node 60). Both clades are weakly supported; in trees that are just one step longer they are not recovered, thus casting doubts about these relationships. These four genera form part of the basal sigmodontine polytomy that results in the parsimony jackknife analysis. Eunemoys and Reithrodon can be forced to form a monophyletic group in trees that are eight steps longer than the most parsimonious ones. Vorontzov (1959 cited in Reig, 1980) placed Reithrodon in its own tribe,
Reithrodontini, a classificatory scheme not followed in recent taxonomic treatises (e.g., McKenna and Bell, 1997). Current molecular evidence supports Vorontzov's view. Future studies, which should include Neotomys, are needed to test the Reithrodon-group polyphyly hypothesis posed here. This test is needed before the $R e$ ithrodon-group biogeographic hypothesis of Ortiz et al. (2000) can be critically assessed. However, a reappraisal, framed within a study with broad taxonomic sampling, of the phylogenetic relationships of the fossil taxa Panchomys, Icthyurodon and Tafimys with regards to Reithrodon and Euneomys seems to be worthwhile due to the strong evidence suggesting the polyphyly of the phyllotine group sensu Olds and Anderson (1989).

The present analysis, while confirming the distinction of oryzomyines and thomasomyines (contra Reig, 1986), fails to recover a monophyletic Oryzomyini (sensu Voss 
Table 7

Unambiguous changes along selected lines of the consensus tree illustrated in Fig. 1

\begin{tabular}{lllcc}
\hline \multirow{2}{*}{ Line } & \multicolumn{2}{l}{ Cyt $b$} & \multirow{2}{l}{ IRBP } \\
\cline { 2 - 4 } & First & Second & Third & \\
\hline Sigmodontinae & 8 & 4 & 15 & 12 \\
$66-65$ & 3 & 5 & 9 & 6 \\
$65-64$ & 4 & 1 & 6 & 0 \\
$64-63$ & 2 & 1 & 18 & 0 \\
$64-61$ & 4 & 0 & 3 & 0 \\
$61-58$ & 1 & 0 & 7 & 0 \\
$58-57$ & 1 & 1 & 7 & 0 \\
$57-54$ & 3 & 0 & 10 & 0 \\
$54-46$ & 1 & 2 & 14 & 0 \\
$46-45$ & 1 & 0 & 9 & 0 \\
$58-38$ Akodontines & 1 & 1 & 11 & 6 \\
54-53 Abrothricines & 0 & 1 & 8 & 9 \\
$45-44$ Oryzomyines & 3 & 1 & 19 & 12 \\
45-43 Phyllotines & 1 & 2 & 7 & 7 \\
\hline
\end{tabular}

Note. Nodes identify lines as follows: the node from which a line originates to the node to which it leads (see node numbers in Fig. 1). Consistency and retention indices for each data class are specified in Table 6.

and Carleton, 1993). As in Smith and Patton (1999), Scolomys falls outside the oryzomyine clade. Twelve additional steps are needed to group Scolomys with Oecomys and Oryzomys. This issue is relevant to further study because in an IRBP solo analysis a monophyletic Oryzomyini is recovered (Weksler, in press). Moreover, considering that Oryzomyini is the largest sigmodontine tribe, the study of additional oryzomyine genera (e.g., Holochilus, Neacomys, Nesoryzomys, and Pseudoryzomys) is much needed.

In a revision of Delomys Voss (1993) suggested that the thomasomyine group was originally delineated (Hershkovitz, 1962, 1966) on the basis of plesiomorphic character states. He (1993, p. 25) added that Delomys, and probably the remaining thomasomyine genera, cannot be assigned to any monophyletic group less inclusive than Sigmodontinae. Later on, Smith and Patton (1999) corroborated the assertion of Voss (1993) with regards to Delomys and Juliomys, although they recovered a more restricted thomasomyine clade formed by Chilomys, Rhipidomys, and Thomasomys. In the present analysis I included Delomys, Juliomys, Rhipidomys, and Thomasomys. None of these genera appears as sister to other thomasomyine genera. In trees 26 steps longer than the most parsimonious, a classical monophyletic thomasomyine group is recovered; meanwhile, 11 additional steps are needed to group Thomasomys with Rhipidomys. Therefore, the simultaneous analysis of cyt $b$ and IRBP DNA sequences corroborates the assertion of Voss with regards to the nature of the thomasomyine group (1993), and refutes that of Smith and Patton (1999). The study of the remaining "thomasomyines," especially Aepeomys and Chilomys as well as those poorly known from eastern South America (e.g., Abrawayaomys, Phaenomys, Rhagomys, and Wilfredomys), is critical to further test the phylogenetic hypothesis here advanced. Finally, this study corroborates Reig's (1980) concept that Wiedomys is the sole living member of Wiedomyini.

\section{The abrothricines}

Perhaps the single most surprising result from the usage of molecular markers in sigmodontine phylogenetics was the finding that a group of taxa mainly distributed in the South and Central Andes (e.g., Abrothrix, Chelemys, Chroeomys, Geoxus, Notiomys, and Pearsonomys), traditionally considered to be typical akodont rodents, and in some cases even considered subgenera of Akodon (Reig, 1987), do not form part of the akodont radiation (Smith and Patton, 1999). The present study, which included four of the six forms (Abrothrix, Chelemys, Chroeomys, and Geoxus), corroborates the monophyly of this Andean group (node 53: $98 \% \mathrm{JK}, \mathrm{BS}=7$ ), which is suggested by both cyt $b$ and IRBP genes as indicated by the PBS values (Table 5). This study also corroborates that the group does not form part of the akodont radiation. In the combined analysis, the Andean clade is sister to a large clade that contains phyllotines, oryzomyines, and Wiedomys. However, these relationships are weakly supported (Fig. 1A), and in the jackknife analysis these lines collapse to the basal sigmodontine polytomy. Smith and Patton (1999, pp. 106-107) suggested ranking this group of genera as a tribe, indicating that an adequate name for it would be Abrotrichini (sic). Although Smith and Patton (1999) enumerated chromosomal, protein, and parasite features that may be used to diagnose the abrothricine group, they did not formally define or diagnose it. These two issues will be focused on an upcoming contribution.

The last point to be considered here with regard to abrothricines is that, as in the studies of Smith and Patton (1993, 1999), the Abrothrix appears to be paraphyletic with respect to Chroeomys jelskii. There are three main alternative taxonomic interpretations of this topology. First, place Chroeomys in synonymy with Abrothrix. Second, apply the name Abrothrix only to $A$. longipilis (type species of the genus and at the base of the clade), and expand Chroeomys to encompass andinus and olivaceus (including xanthorhinus, see Pearson and Smith, 1999). Third, while restricting Abrothrix to A. longipilis and Chroeomys to C. jelskii, andinus, and olivaceus would need to be placed in their own genus (i.e., three taxa ranked at the generic level). I think that due to the low degree of morphologic variation found among these forms, the best classificatory scheme is to place all forms in Abrothrix. 


\section{The akodontines}

An akodontine group can be traced to Thomas (1916, 1918) who recognized the morphologic resemblance between Akodon and some other taxa he ranked as genera (e.g., Abrothrix, Chroeomys, Deltamys, Hypsimys, Necromys (=Bolomys), Thalpomys, and Thaptomys). Four decades later, Vorontzov (1959 cited in Reig, 1987) coined the term Akodontini for this assemblage. However, it was Reig $(1978,1984,1987)$ who made the most important contribution towards delimiting the group and clarifying its evolutionary history. Reig's (1987) contribution was the last of a series of studies of akodontine macrosystematics framed within the evolutionary systematics approach. During this period, much of the debate on akodontine taxonomy and systematics was centered on issues at low taxonomic levels (see below); meanwhile, the contents of the group remained more or less stable. The major disagreement revolved around Oxymycterus and similar genera (e.g., Lenoxus, Podoxymys), which have been placed in a different but closely related "oxymycterine" group (Hershkovitz, 1966; Hopper and Musser, 1964) or Oxymycterini tribe (Massoia, 1981); or have been included within Akodontini by others (Reig, 1980, 1987). This last position has been followed in the most recent treatise of mammal taxonomy (McKenna and Bell, 1997).

The availability of sequence data prompted a major redefinition of the contents of Akodontini. The most surprising result was the identification and removal of the abrothricine group (see above). In addition, Smith and Patton (1999) provided evidence by indicating that two genera, Scapteromys and Kunsia, placed traditionally in a separate tribe Scapteromyini (Massoia, 1979), fall into the akodont radiation. Recently, D'Elía et al. (in press b) expanded this result by finding that Bibimys, the third scapteromyine genus, is an akodont. The present study further tests these novel hypotheses, and also sheds new light on issues at lower taxonomic levels.

A large clade in agreement with Smith and Patton's (1999) conception of the akodontine tribe (see Table 1) was recovered with high levels of support (node 38 in Fig. $1 \mathrm{~B}, \mathrm{JK}=97 \%, \mathrm{BS}=6$ ). This clade appears as sister to a large clade containing abrothricines, phyllotines, oryzomyines and several genera without clear phylogenetic relationships (see above). This relationship is only weakly supported, but it should be taken into consideration until new evidence falsifies it. The evidence at hand refutes Reig's $(1986,1987)$ hypotheses of akodontines having evolved from an oryzomyine stock, and in turn having given rise to phyllotines. According to the present hypothesis, both phyllotines and oryzomynes are only distantly related to akodonts. However, phyllotines and oryzomynes are closely related to the abrothricines (Fig. 1A); this fact may, in part, explain why Reig, who considered abrothricines to be typical akodonts, suggested a phylogenetic relation among oryzomyines, akodontines, and phyllotines.

The akodontine clade (sensu Smith and Patton, 1999) appears well resolved and formed by five main clades that are related to each other as follows: $((A, B))(C)$ E))) (see Fig. 1B). This clade notation will be used in the follow-up discussion, where I will first focus on each one of these clades individually, to then discuss the relationships among them.

Clade A (node 33 in Fig. $1 \mathrm{~B}, \mathrm{JK}=84 \%, \mathrm{BS}=3$ ) contains middle and large size rats, the fossorial Kunsia, the largest known living sigmodontine, and the semiaquatic Scapteromys. Of the five main akodontine clades, clade $\mathrm{A}$ is the only one not supported by IRBP characters. Clade $\mathrm{B}(\mathrm{JK}=81 \%, \mathrm{BS}=3)$ is composed of Blarinomys, Brucepattersonius, and Lenoxus. These three genera were classically considered to be closely related to Oxymycterus (e.g., Hershkovitz, 1998; Massoia and Fornes, 1969; Thomas, 1909) and as such, they are placed in the oxymycterine group (Hershkovitz, 1966; Hopper and Musser, 1964). In fact, the monotypic Lenoxus and Blarinomys were erected to highlight the morphologic distinction of two species initially assigned to Oxymycterus (Thomas, 1896, 1909). Brucepattersonius was recently limited to five newly described species together with one species formerly assigned to $O x y$ mycterus (Hershkovitz, 1998). However, Oxymycterus (four species included) and Juscelinomys form part of the akodont clade $\mathrm{C}(\mathrm{JK}=100, \mathrm{BS}=18)$, which is not sister to clade B. Bibimys, which was previously placed along with Scapteromys and Kunsia in the scapteromyine group (Table 1), is the sole member of the akodont clade D. Bibimys is sister to clade E.

Clade $\mathrm{E}(\mathrm{JK}=100 \%$; $\mathrm{BS}=22)$ is composed by those taxa on which, classically, the debate on akodontine taxonomy and systematics has focused (reviewed in Reig, 1987). At the peak practice of typological taxonomy, several taxa were named to encompass species that are morphologically similar to Akodon but distinguishable from it by one or two trenchant characters. For instance, Thomas (1918) erected Hypsimys to contain a species characterized by its high-crown molars; Microxus and Thalpomys are separated from Akodon by the slope of the zygomatic plate and a ridged interorbital region, respectively (Thomas, 1909, 1916). These taxa, together with Deltamys, Necromys (=Bolomys), and Thaptomys have alternatively been considered either synonyms, subgenera of Akodon, or genera depending on the relative weight given to these and few other characters (e.g., Cabrera, 1961; Ellerman, 1941; Gyldenstolpe, 1932; Hershkovitz, 1990, 1998; Reig, 1987; Tate, 1932).

I have included samples of the three subgenera of Akodon as currently recognized (Akodon, Microxus, and Hypsimys). The subgenus Akodon appears paraphyletic with respect to A. (Microxus) mimus and A. (Hypsimys) 
siberiae, implying that both subgenera should be regarded as synonyms of Akodon. It must be noted that $A$. (H.) budini, type species of Hypsimys, was not included in this study. Similarly, it may prove worthwhile to also analyze $A$. bogotensis, a species referred to Microxus (Reig, 1987), that according to some authors (e.g., Patton et al., 1989) differs more from typical Akodon than A. (M.) mimus, the type species of Microxus. The monotypic Deltamys appears as sister to Akodon, corroborating the phenetic analysis of González and Massoia (1995) that ranked Deltamys at the genus level.

The poorly studied Thalpomys, a taxon that has not previously been included in a phylogenetic analysis, is sister to Necromys (=Bolomys; see Massoia and Pardiñas, 1993 and additional nomenclatorial comments in Galliari and Pardiñas, 2000). Hershkovitz (1990), who acknowledged the cranial resemblance between these two taxa, anticipated this relationship. However, he put special emphasis on the ranking of Thalpomys at the genus level due to the distinctiveness of its molars and pelage (Hershkovitz, 1990, p. 767).

Necromys is a genus on which several ecological studies have been based (e.g., De Lima et al., 1995; Oliveira et al., 1998), but which is still in great need of revision. Problems range from nomenclatural issues, to species limits, to the delimitation of the genus itself (Anderson and Olds, 1989; Galliari and Pardiñas, 2000; Reig, 1987). An important issue of Necromys systematics has been whether forms from the grasslands of southern and northern South America and the Central Andes form a monophyletic group or not. Based on a phylogenetic analysis of $801 \mathrm{bp}$ of the cyt $b$ gene Smith and Patton (1993) found that urichi, a northern form classically referred to the genus Akodon and either placed in the subgenus Chalcomys or in the nominate subgenus (e.g., Reig, 1987; Thomas, 1916; Ventura et al., 2000), was sister to $N$. lasiurus. In addition, Smith and Patton (1993) found that amoenus, type species of Bolomys, was not sister to the lasiurus-urichi clade. Based on this result, Galliari and Pardiñas (2000, p. 226) suggested that Bolomys should be retained to encompass amoenus. Later, Smith and Patton (1999) in a phylogenetic analysis based on the whole cyt $b$ gene recovered a monophyletic group composed by amoenus, lasiurus, and urichi, placing all forms in one genus. I have included these three taxa in addition to a second form, temchuki, from southern South America. The simultaneous analysis corroborates Smith and Patton's (1999) study, in that all of these species form a well supported natural group (node 15 in Fig. $1 \mathrm{~B}, \mathrm{JK}=99 \%, \mathrm{BS}=9$ ), which provides preliminary support for the recognition of only one genus, Necromys, to encompass all forms. Considering the polytomy at the base of this clade (node 15 Fig. 1B), another option may be to recognize three genera: Necromys for the morphologically homogeneous southern forms, retain Bolomys for amoenus, and erect a new genus for urichi (urichi was earlier placed in the subgenus Chalcomys; however the type species of this taxon, aerosus, which was not included in the present study, falls into the Akodon clade in phylogenetic analyses of cyt $b$ and control region sequences; D'Elía et al., in press a; Hoekstra and Edwards, 2000; Smith and Patton, 1991). Here I place all forms in Necromys. This hypothesis should be further tested with the inclusion of additional forms such as benefactus (type species of Necromys), lactens, obscurus, and punctulatus. This work is underway. The inclusion of urichi in Necromys is important because as a result, Necromys is no longer composed exclusively of species with a $2 n=33 / 34(N$. urichi has a diploid complement of $2 n=18$; Reig et al., 1971). Karyotypic homogeneity was one of the primary arguments Reig (1987, p. 356) used to delimit Necromys (regarded as Bolomys at that time).

In a phylogenetic analysis based on cyt $b$ sequences, which included a broad sampling of Akodon species, D'Elía et al. (in press a) found that Akodon serrensis, which has always been referred to the typical subgenus of Akodon (Musser and Carleton, 1993; Reig, 1987), falls well outside the Akodon clade. This phylogenetic hypothesis receives further support here. Ten extra steps are needed to force $A$. serrensis within the Akodon clade. A. serrensis appears to be sister to the monotypic genus Thaptomys (node 18), although this relationship is weakly supported $(\mathrm{JK}<50 \%, \mathrm{BS}=1)$. This clade is sister to the clade Thalpomys-Necromys. Further studies, including morphological comparisons and the sequencing of additional specimens, are needed to determine if $A$. serrensis should be placed on its own genus or in Thaptomys. Interestingly, both A. serrensis and Thaptomys are distributed in the Atlantic rainforest, a fact that reinforces the extreme importance of this region as a center of mammal diversification (da Silva and Patton, 1998; Smith and Patton, 1999).

The last topic to be covered on akodont systematics is that of the relationships among the five recently discussed natural groups, which made up Akodontini, as recently redefined by Smith and Patton (1999). These clades relate to each other as follows: ((A, B) $(\mathrm{C}(\mathrm{D}, \mathrm{E})))$; however, this topology is weakly supported. In the jackknife analysis (Fig. 1B), after nodes with less than $50 \%$ of support are allowed to collapse, the resulting topology is: $(\mathrm{A}, \mathrm{B}(\mathrm{C}, \mathrm{D}, \mathrm{E}))$. Taken altogether, these results indicate that further work is needed to clarify the basal pattern of the akodontine differentiation. The inclusion of Podoxymys, the only akodontine taxon currently ranked at the genus level not included in this study, may help to resolve the tree.

For the time being, it seems adequate to continue to recognize Akodontini (sensu Smith and Patton, 1999). However, in order to emphasize the current knowledge of the phylogenetic relationships within this large clade, it is of interest to informally recognize well-supported 
internal divisions of akodonts. Five akodont divisions could be recognized: (1) the Akodon Division, formed by Akodon, Deltamys, Necromys, Thalpomys, and Thaptomys, which is equivalent to the akodontine tribe sensu stricto; (2) the Blarinomys Division consisting of Blarinomys, Brucepattersonius, and Lenoxus; (3) the Oxymycterus Division containing Oxymycterus and Juscelinomys; (4) the Scapteromys Division consisting of Scapteromys and Kunsia; and (5) the Bibimys Division, formed only by Bibimys, a genus that cannot be placed with certainty in any group less inclusive than the akodontine tribe.

\section{Comments on the historical biogeography of the sig- modontinae}

I will close this contribution by commenting on the historical biogeography of Sigmodontinae. The study of sigmodontine historical biogeography (SHB) is one of the most remarkable chapters of Neotropical mammalogy, but it is also the focus of major disagreements. Most of the scenarios advanced in this respect (see a recent review by Pardiñas et al., 2002) are based on geographic and temporal distribution of both extant and extinct forms, and rest on hypotheses of phylogenetic relationships falsified at the light of the present phylogeny and those recently hypothesized elsewhere (e.g., Smith and Patton, 1999).

Recently acquired fossil evidence is helping to reshape the study of SHB. In fact, new chronostratigraphic work (Pardiñas and Tonni, 1998) together with the discovery of new fossil material (reviewed in Pardiñas et al., 2002) showed that past sigmodontine diversity was greater than had been acknowledged, and that the South American diversification of the group started earlier than previously recognized. Around 5$6 \mathrm{Myr}$ ago distinctive sigmodontine lines already inhabited what today are the central Argentinean provinces of Buenos Aires and La Pampa. However, additional work involving fossil taxa is much needed. A critical reassessment, within a cladistic framework and with a broad taxonomic coverage, of the sigmodontine condition of some North American fossil forms (e.g., Abelmoschomys, Prosigmodon, and Symmetrodontomys) as well as the integration of South American sigmodontine fossils into formal cladistic analyses (see an example in Steppan and Pardiñas, 1998) is much needed to shed light on the placement and timing of the sigmodontine basal radiation.

In framing their views of sigmodontine paleobiogeography, several authors have hypothesized different sigmodontine taxa to be the sister or paraphyletic with respect to the remaining sigmodontines. This subject largely falls out of the scope of this contribution, and I refer the reader to Pardiñas et al. (2002) for a synthesis of the different scenarios. Here, I will simply describe the two positions that framed the debate on SHB during the 1980 's and have served as a foundation for most papers since then. Baskin $(1978,1986)$, based on dental morphology, suggested that Bensomys, a North American fossil taxon, is in fact a junior synonym of the extant South American genus Calomys. This led to the suggestion that sigmodontines diversified early in North America prior to their entrance into South America (Baskin, 1986; Czaplewski, 1987). On the other hand, Reig (1980, 1986; see also Steppan, 1995) denied that Bensonomys represents the genus Calomys and suggested that the oryzomyines represent the group that gave rise to the sigmodontines in a radiation that took place in South America. The present study suggests that phyllotines (including Calomys) and oryzomyines are neither sister to the remaining sigmodontines nor paraphyletic with respect to them. Instead, Sigmodon represents the sister group of the remaining living sigmodontines. This phylogenetic relationship is corroborated by other phylogenetic studies (D'Elía et al., in press a; Engel et al., 1998). In addition, in an IRBP solo analysis a clade composed by Sigmodon and an ichthyomyine (Rheo$m y s)$, a group not represented in the present study or in those of Engel at al. (1998) and D'Elía et al. (in press a), was recovered as sister to the remaining sigmodontines (Weksler, in press). These results falsify both Baskin (1978, 1986) and Reig (1980, 1986) hypotheses of sigmodontine historical biogeography in regards to the taxa involved in the cladogenetic event at the base of the sigmodontine clade. However, more work is needed in order to clarify the placement of the sigmodontine basal radiation. Among the research that must be undertaken is a taxon dense cladistic analysis that includes all Sigmodon and ichthyomyine species, which are distributed in South, Central, and North America, to further test their sistergroup relationships to the remaining living sigmodontines, and to optimize on the phylogeny the geographic location of the sigmodontine common ancestor.

\section{Final considerations}

The widespread adoption of an explicit cladistic approach for studying sigmodontine phylogenetics has prompted major changes in the group's classification. For example, the realization that several sigmodontine genera (e.g., Irenomys, Juliomys) cannot be placed into any monophyletic group less inclusive than Sigmodontinae (Smith and Patton, 1999; Voss, 1993) prompts basically two classificatory alternatives: (a) to erect monogeneric tribes for each of these genera, or (b) to simply consider them as Sigmodontinae incertae sedis. I agree with Voss (1993) and Smith and Patton (1999) in that the latter view is preferable, because the proliferation of such taxa (and names) would not provide any 
additional information to systematists. Then, the suprageneric taxa should only be used (and erected) for those well-supported clades, while those genera without clear phylogenetic relationships do not have to be forced into tribes. This assertion is not in contradiction with continuing the usage of tribes that are only composed by one living genus each (i.e., Sigmodontini, Reithrodontini, and Wiedomyini). This practice is justified in first place by the availability of these names. Second, in addition to Wiedomys, Wiedomyini includes the extinct Cholomys (Reig, 1980). Similarly, the tribe Sigmodontini also includes the extinct Prosigmodon. Besides testing the just mentioned groups, future cladistic work will clarify if the extinct Ichthyurodon, Panchomys, and Tafimys belong to Reithrodontini, Phyllotini or to neither of them. As our picture of sigmodontine phylogenetics is incomplete, other changes in sigmodontine classification are expected. To further our knowledge on this subject it is of particular relevance for the upcoming cladistic analyses to use a broader taxonomic sampling than the one employed here (i.e., especially one including ichthyomyines and Aepeomys, Abrawayaomys, Phaenomys, Rhagomys and Wilfredomys). Similarly, the combined analysis of morphological and molecular evidence is much needed. Such a simultaneous analysis helps to clarify those areas of the sigmodontine radiation where morphological and molecular evidence seems to be in conflict (e.g., the monophyly of the Reithrodon group and its placement within Phyllotini are strongly corroborated by morphological characters but falsified by present molecular evidence). All of these studies will favour the availability of a well-corroborated sigmodontine topology, which would constitute the necessary base to: (a) cladistically delimit and diagnose sigmodontine suprageneric groups (see Steppan, 1995), and) (b) pose robust tests of evolutionary hypotheses involving Sigmodontinae.

\section{Acknowledgments}

I thank Phil Myers, Ulyses Pardiñas, Mike Carleton, Bill Fink, Diarmaid Ó Foighil, Arnold Kluge, and three anonymous referees for critically reviewing earlier versions of this contribution. Patricia Draper greatly improved the writing of this paper. I am grateful to the curators and colleagues who generously loaned me voucher specimens and tissue samples. In this regard, my special thanks go to Jim Patton (Museum of Vertebrate Zoology) and Ulyses Pardiñas (Centro Nacional Patagónico); I also thank Maria José Silva and Yatiyo Yassuda (Universidade de São Paulo), Lena Geise (Universidade do Estado do Rio de Janeiro), Robert Voss (American Museum of Natural History), Jorge Salazar-Bravo and Terry Yates (Museum of Southwestern Biology), Robert Baker and Robert Owen
(Texas Tech University), and Louise Emmons (Smithsonian Institution). The University of Michigan Museum of Zoology, Rackham School of Graduate Studies, and Department of Ecology and Evolutionary Biology provided financial support.

\section{References}

Anderson, S., Olds, N., 1989. Notes on Bolivian mammals. 5. Taxonomy and distribution of Bolomys (Muridae, Rodentia). Am. Mus. Novitates 2935, 1-22.

Anderson, S., Yates, T.L., 2000. A new genus and species of phyllotine rodent from Bolivia. J. Mammal. 81, 18-36.

Apfelbaum, L.I., Reig, O.A., 1989. Allozyme genetic distances and evolutionary relationships in species of akodontine rodents (Cricetidae: Sigmodontinae). Biol. J. Linn. Soc. 38, 257-280.

Baker, F.K., Lutzoni, F.M., 2002. The utility of the incongruence length difference test. Syst. Biol. 51, 625-637.

Baker, R.H., De Salle, R., 1997. Multiple sources of character information and the phylogeny of Hawaiian Drosophilids. Syst. Biol. 46, 654-673.

Barrantes, G.E., Ortells, M.O., Reig, O.A., 1993. New studies on allozyme genetic distance and variability in akodontine rodents (Cricetidae) and their systematic implications. Biol. J. Linn. Soc. 48, 283-298.

Baskin, J.A., 1978. Bensonomys, Calomys, and the origin of the phyllotine group of Neotropical cricetines (Rodentia, Cricetidae). J. Mammal. 59, 125-135.

Baskin, J.A., 1986. The late Miocene radiation of Neotropical sigmodontine rodents in North America. In: Flanagan K.M., Lillegraven, J.A. (Eds.), Vertebrates, Phylogeny, and Philosophy. University of Wyoming Contributions to Geology. Special Paper 3, pp. 287-303.

Bonvicino, C., Moreira, M.A.M., 2001. Molecular phylogeny of the genus Oryzomys (Rodentia: Sigmodontinae) based on cytochrome $b$ DNA sequences. Mol. Phylogenet. Evol. 18, 282-292.

Braun, J., 1993. Systematic relationships of the tribe Phyllotini (Muridae: Sigmodontinae) of South America. Oklahoma Mus. Nat. Hist. Special Publications. 1-50.

Bremer, K., 1994. Branch support and tree stability. Cladistics 10, 295-304

Brower, A.V.Z., De Salle, R., Vogler, A., 1996. Gene trees, species trees and systematics: a cladistic perspective. Annu. Rev. Ecol. Syst. 27, 423-450

Bull, J.J., Huelsenbeck, J.P., Cunningham, C.W., Swofford, D.L., Waddell, P.J., 1993. Partitioning and combining data in phylogenetic analysis. Syst. Biol. 42, 384-397.

Cabrera, A., 1961. Catálogo de los Mamíferos de América del Sur. Rev. Mus. Argentino Cien. Nat. "Bernardino Rivadavia”, Ciencias Zoológicas 4, xxii + 309-732.

Chiappero, M.B., de Sousa, G.B., Blanco, A., Gardenal, C.N., 2002. Evolutionary relationships among eight species of South American phyllotine rodents (Rodentia: Muridae) based on allozyme data. J. Zool. Syst. Evol. Res. 40, 1-7.

Czaplewski, N.J., 1987. Sigmodont rodents (Mammalia; Muroidea; Sigmodontinae) from the Pliocene (early Blancan) Verde Formation, Arizona. J. Vertebr. Paleontol. 7, 183-199.

da Silva, M.N.F., Patton, J.L., 1993. Amazonian phylogeography: mtDNA sequence variation in arboreal echimyid rodents (Caviomorpha). Mol. Phylogenet. Evol. 2, 243-255.

da Silva, M.N.F., Patton, J.L., 1998. Molecular phylogeography and the evolution and conservation of Amazonian mammals. Mol. Ecol. 7, 475-486. 
D'Elía, G., 2000. Comments on recent advances in understanding sigmodontine phylogeny and evolution. Mastozool. Neot. 7, 47-54.

D’Elía, G., González, E.M., Pardiñas, U.F.J., in press a. Phylogenetic analysis of sigmodontine rodents (Muroidea), with special reference to the akodont genus Deltamys. Mammal. Biol.

D'Elía, G., Pardiñas, U.F.J., Myers. P., in press b. An introduction to the genus Bibimys (Rodentia: Sigmodontinae): phylogenetic position and alpha taxonomy. In: Lacey, E., Myers, P. (Eds.), Mammalian Diversification: from Population Genetics to Biogeography. University of California Press, Berkeley.

De Lima, F.A., Magnusson, W.E., Sanaiotti, T.M., 1995. Variation in growth and reproduction of Bolomys lasiurus (Rodentia: Muridae) in an Amazonian savanna. J. Trop. Ecol. 11, 419-428.

de Queiroz, A., Donoghue, M.J., Kim, J., 1995. Separate versus combined analysis of phylogenetic evidence. Annu. Rev. Ecol. Syst. 26, 657-681.

De Salle, R., Brower, A.V.Z., 1997. Process partitions, congruence, and the independence of characters: inferring relationships among closely related Hawaiian Drosophila from multiple gene regions. Syst. Biol. 46, 751-764.

Dickerman, A.W., 1992. Molecular systematics of some new world muroid rodents. Ph.D. Dissertation, University of Wisconsin, Madison.

Eernisse, D.J., Kluge, A.G., 1993. Taxonomic congruence versus total evidence, and amniote phylogeny inferred from fossils, molecules, and morphology. Mol. Biol. Evol. 10, 1170-1195.

Ellerman, J.R., 1941. The Families and Genera of Living Rodents. Vol. 2, Family Muridae. British Museum of Natural History, London.

Emmons, L.H., 1999. Two new species of Juscelinomys (Rodentia: Muridae) from Bolivia. Am. Mus. Novitates 3280, 1-15.

Engel, S.R., Hogan, K.M., Taylor, J.F., Davis, S.K., 1998. Molecular systematics and paleobiogeography of the South American sigmodontine rodents. Mol. Biol. Evol. 15, 35-49.

Farris, J.S., 1982. The logical basis of phylogenetic analysis. In: Platnick, N., Funk, V. (Eds.), Advances in Cladistics: Proceedings of the Second Meeting of the Willi Hennig Society. Columbia University Press, New, pp. 7-36.

Farris, J.S., Källersjö, M., Kluge, A.G., Bult, C., 1994. Testing significance of incongruence. Cladistics 10, 315-319.

Farris, J.S., Källersjö, M., Kluge, A.G., Bult, C., 1995. Constructing a significance test for incongruence. Syst. Biol. 44, 570-572.

Farris, J.S., Albert, V.A., Källersjö, M., Lipscomb, D., Kluge, A.G., 1996. Parsimony jackknifing outperforms neighbor-joining. Cladistics 12, 99-124.

Galliari, C.A., Pardiñas, U.F.J., 2000. Taxonomy and distribution of the sigmodontine rodents of genus Necromys in central Argentina and Uruguay. Acta Theriol. 45, 211-232.

González, E.M., Massoia, E., 1995. Revalidación del genero Deltamys Thomas, 1917, con la descripción de una nueva subespecie de Uruguay y sur del Brasil (Mammalia: Rodentia: Cricetidae). Com. Zool. Mus. Hist. Nat. Montevideo 182, 1-8.

Gyldenstolpe, N., 1932. A manual of Neotropical sigmodont rodents. Kunglia Svenska Vetenskapsakademiens Handlingar, Stockholm (ser. 3) 11, 1-164.

Hershkovitz, P., 1962. Evolution of Neotropical cricetine rodents (Muridae) with special reference to the phyllotine group. Fieldiana: Zool. 46, 1-524.

Hershkovitz, P., 1966. South American swamp and fossorial rats of the Scapteromyine group (Cricetinae, Muridae), with comments on the glans penis in murid taxonomy. Z. Saugetier. 31, 81-149.

Hershkovitz, P., 1998. Report on some sigmodontinae rodents collected in southeastern Brazil with description of a new genus and six new species. Bonn. Zool. Beitr. 47, 193-256.

Hershkovitz, P., 1990. The Brazilian rodent genus Thalpomys (Sigmodontinae, Cricetidae) with a description of a new species. J. Nat. Hist. 24, 763-783.
Hoekstra, H.E., Edwards, S.V., 2000. Multiple origins of XY female mice (genus Akodon): phylogenetic and chromosomal evidence. Proc. R. Soc. Lond. B 267, 1825-1831.

Hopper, E.T., Musser, G.G., 1964. The glans penis in Neotropical cricetines (family Muridae) with comments on classification of muroid rodents. Mis. Pub. Mus. Zool. Univ. Michigan 123, 1-57.

Huelsenbeck, J.P., Bull, J.J., Cunningham, C.W., 1996. Combining data in phylogenetic analysis. Trends Ecol. Evol. 11, 152-158.

Jansa, S.A., Voss, R.S., 2000. Phylogenetic studies on didelphid marsupials. I. Introduction and preliminary results from nuclear IRBP gene sequences. J. Mammal. Evol. 7, 43-77.

Kluge, A.G., 1989. A concern for evidence and a phylogenetic hypothesis of relationships among Epicrates (Boidae, Serpentes). Syst. Zool. 38, 7-25.

Kluge, A.G., 2002. Distinguishing "or" from "and" and the case for historical identification. Cladistics 18, 585-593.

Kluge, A.G., Farris, J.S., 1969. Quantitative Phyletics and the Evolution of Anurans. Syst. Zool. 18, 1-32.

Malygin, V.M., Aniskin, V.M., Isaev, S.I., Milishnikov, A.N., 1994. Amphinectomys savamis Malygin gen. Et sp. n., a new genus and a new species of water rat (Cricetidae, Rodentia) from Peruvian Amazonia. Zool. Zhur. 73, 195-208.

Massoia, E., 1979. Descripción de un género y especie nuevos: Bibimys torresi (Mammalia-Rodentia Cricetidae-Sigmodontinae-Scapteromyni). Physis C 38, 1-7.

Massoia, E., 1981. Notas sobre los cricétidos mendocinos (Mammalia, Rodentia). Hist. Nat. 1, 205-208.

Massoia, E., Fornes, A., 1969. Caracteres comunes y distintivos de Oxymycterus nasutus (Waterhouse) y O. iheringi Thomas (Rodentia, Cricetidae). Physis 28, 315-321.

Massoia, E., Pardiñas, U.F.J., 1993. El estado sistemático de algunos muroideos estudiados por Ameghino en 1889. Revalidación del género Necromys (Mammalia, Rodentia, Cricetidae). Ameghiniana 30, 407-418.

McKenna, M.C., Bell, S.K., 1997. Classification of Mammals above the Species Level. Columbia University Press, New York.

Miyamoto, M.M., Fitch, W.M., 1995. Testing species phylogenies and phylogenetic methods with congruence. Syst. Biol. 44, 64-76.

Musser, G.G., Carleton, M.D., 1993. Family muridae. In: Wilson, D.E., Reeder, D.M. (Eds.), Mammal Species of the World: a Taxonomic and Geographic Reference. Smithsonian Institution Press, Washington, pp. 501-755.

Myers, P., Lundrigan, B.L., Tucker, P.K., 1995. Molecular phylogenetics of oryzomyine rodents: the genus Oligoryzomys. Mol. Phylogenet. Evol. 4, 372-382.

Nelson, G., 1979. Cladistic analysis and synthesis: principles and definitions, with a historical not on Adanson's Familles des Plantes (1763-1764). Syst. Zool. 28, 1-21.

Nixon, K.C., 1999. Winclada (BETA) ver. 0.9.9 Published by the author, Ithaca, NY.

Nixon, K.C., Carpenter, J.M., 1993. On outgroups. Cladistics 9, 413 426.

Nixon, K.C., Carpenter, J.M., 1996. On consensus, collapsibility, and clade concordance. Cladistics 12, 305-321.

Olds, N., Anderson, S., 1989. A diagnosis of the tribe Phyllotini (Rodentia, Muridae). In: Redford, K.H., Eisenberg, J.F. (Eds.), Advances in Neotropical Mammalogy. FL Sandhill Crane Press, Gainesville, pp. 55-74.

Oliveira, J.A., Strauss, R.E., dos Reis, S.F., 1998. Assessing relative age and age structure in natural populations of Bolomys lasiurus (Rodentia: Sigmodontinae) in northeastern Brazil. J. Mammal. 79, 1170-1183.

Ortiz, P., Pardiñas, U.F.J., Steppan, S., 2000. A new fossil phyllotine (Rodentia: Muridae) from Northwestern Argentina and the relationships of Reithrodon group. J. Mammal. 81, 37-51.

Patton, J.L., Myers, P., Smith, M.F., 1989. Electromorphic variation in selected South American akodontine rodents (Muridae: 
Sigmodontinae), with comments on systematic implications. Z Saugetier. 54, 347-359.

Pardiñas, U.F.J., 1997. Un nuevo sigmodontino (Mammalia, Rodentia) del Plioceno de Argentina y consideraciones sobre el registro fósil de los Phyllotini. Rev. Chi. Hist. Nat. 70, 543-555.

Pardiñas, U.F.J., Tonni, E., 1998. Procedencia estratigráfica y edad de los más antiguos muroideos (Mammalia, Rodentia) de América del Sur. Ameghiniana 35, 473-475.

Pardiñas, U.F.J., D’Elía, G., Ortiz, P.E., 2002. Sigmodontinos fósiles (Rodentia, Muroidea, Sigmodontinae) de América del Sur: estado actual de su conocimiento y prospectiva. Mastozool. Neotrop. 9, 209-252.

Pearson, O.P., Smith, M.F., 1999. Genetic similarity between Akodon olivaceus and Akodon xanthorhinus (Rodentia: Muridae) in Argentina. J. Zool., Lond. 247, 43-52.

Reig, O.A., 1978. Roedores cricétidos del Plioceno superior de la provincia de Buenos Aires (Argentina). Pub. Mus. Mun. Cien. Nat. Mar del Plata "Lorenzo Scaglia" 2, 164-190.

Reig, O.A., 1980. A new fossil genus of South American cricetid rodents allied to Weidomys, with an assessment of the Sigmodontinae. J. Zool., Lond. 192, 257-281.

Reig, O.A., 1984. Distribução geográphica e história evolutiva dos roedores muroideos sulamericanos (Cricetidae: Sigmodontinae). Rev. Bras. Gen. 7, 333-365.

Reig, O.A., 1986. Diversity patterns and differentiation of high Andean rodents. In: Vuillemier, F., Monasterio, M. (Eds.), High Altitude Tropical Biogeography. Oxford University Press, New York, pp. 404-439.

Reig, O.A., 1987. An assessment of the systematics and evolution of the Akodontini with the description of new fossil species of Akodon (Cricetidae: Sigmodontinae). Fieldiana: Zool. 39, 347-399.

Reig, O.A., Kiblisky, P., Linares, O.J., 1971. Datos sobre Akodon urichi venezuelensis (Rodentia: Cricetidae). Acta Biol. Venez. 7, 157-189.

Siddall, M.E., 1997. Prior agreement: arbitration or arbitrary? Syst. Biol. 46, 765-769.

Smith, M.F., Patton, J.L., 1991. Variation in mitochondrial cytochrome $b$ sequence in natural populations of South American akodontine rodents (Muridae: Sigmodontinae). Mol. Biol. Evol. 8, 85-103.

Smith, M.F., Patton, J.L., 1993. The diversification of South American murid rodents: evidence from mitochondrial DNA sequence data for the akodontine tribe. Biol. J. Linn. Soc. 50, 149-177.

Smith, M.F., Patton, J.L., 1999. Phylogenetic relationships and the radiation of sigmodontine rodents in South America: Evidence from cytochrome $b$. J. Mammal. Evol. 6, 89-128.

Sorenson, M.D., 1999. TreeRot, version 2. Boston University, Boston, MA.
Steppan, S.J., 1995. Revision of the Tribe Phyllotini (Rodentia: Sigmodontinae), with a phylogenetic hypothesis for the Sigmodontinae. Fieldiana: Zool. 80, 1-112.

Steppan, S.J., 1998. Phylogenetic relationships and species limits within Phyllotis (Rodentia: Sigmodontinae): concordance between mtDNA sequence and morphology. J. Mammal. 79, 573-593.

Steppan, S.J, Pardiñas, U.F.J., 1998. Two new fossil muroids (Sigmodontinae: Phyllotini) from the early Pleistocene of Argentina: phylogeny and paleoecology. J. Vertebr. Paleontol. 18, 640 649

Swofford, D., 2000. PAUP*: Phylogenetic Analysis Using Parsimony (* and other methods), 4.0. Sinauer Associates, Sunderland, USA.

Tate, G.H.H., 1932. The taxonomic history of the South and Central American akodont rodent genera: Thalpomys, Deltamys, Thaptomys, Hypsimys, Bolomys, Chroeomys, Abrothrix, Scotinomys, Akodon, (Chalcomys and Akodon), Microxus, Podoxymys, Lenoxus, Oxymycterus, Notiomys, and Blarinomys. Am. Mus. Novitates 582, $1-32$.

Thomas, O., 1896. On new small mammals from the Neotropical region. Ann. Mag. Nat. Hist. (ser. 6) 18, 310-316.

Thomas, O., 1909. Notes on some South American mammals, with descriptions of new species. Ann. Mag. Nat. Hist. (ser. 8) 4, 230242.

Thomas, O., 1916. The grouping of the South American Muridae commonly referred to Akodon. Ann. Mag. Nat. Hist. (ser. 18) 18, 336-340.

Thomas, O., 1918. On small mammals from Salta and Jujuy collected by Mr. E. Budin. Ann. Mag. Nat. Hist. (Ser. 9) 1, 186-193.

Thompson, J.D., Gibson, T.J., Plewniak, F., Jeanmougin, F., Higgins, D.G., 1997. The Clustal X windows interface: flexible strategies for multiple sequence alignment aided by quality analysis tools. Nucleic Acids Res. 24, 4876-4882.

Ventura, J., Lopez-Fuster, M.J., Salazar, M., Perez-Hernandez, R., 2000. Morphometric analysis of some Venezuelan akodontine rodents. Neth. J. Zool. 50, 487-501.

Vorontzov, N.N., 1959. Sistema khomiakov (Cricetinae) mirovoi fauny i ikh filogeneticheskie sviazi. Biul. Mosk. Obsh. Ispi. Prirody, Otd. Biol. 44, 134-137.

Voss, R., 1993. A revision of the Brazilian Muroid rodent genus Delomys with remarks on "Thomasomyine" characters. Am. Mus. Novitates 3073, 1-44.

Voss, R., Carleton, M., 1993. A new genus for Hesperomys molitor Winge and Holochilus magnus Hershkovitz (Mammalia, Muridae) with an analysis of its phylogenetic relationships. Am. Mus. Novitates 3085, 1-39.

Voss, R.S., Gómez-Laverde, M., Pacheco, V., 2002. A new genus for Aepeomys fuscatus Allen, 1912, and Oryzomys intectus Thomas, 1921: enigmatic murid rodents from andean cloud forests. Am. Mus. Novitates 373, 1-42. 